\title{
ANALISIS POLA REKRUTMEN DAN SELEKSI KARYAWAN DI BRI SYARIAH (Studi di BRI Syariah Kantor Pusat Jakarta)
}

\section{PATTERN ANALYSIS OF RECRUITMENT AND SELECTION OF EMPLOYEES IN BRI Sharia (Studies in BRI Sharia Jakarta Head Office)}

\author{
Nur Rohmatin'1aAndri Brawijaya ${ }^{2 b}$ \\ 1aJurusan Ekonomi Islam Fakultas Ekonomi Islam Universitas Djuanda, Jl. Tol Ciawi No. 1, \\ Kotak Pos 35 Bogor 16720 \\ 2b Jurusan Perbankan Syariah Fakultas Ekonomi Islam Universitas Djuanda, Jl. Tol Ciawi No. \\ 1, Kotak Pos 35 Bogor 16720
}

E-mail:1arohmatin777@gmail.com,2bandri_brawijaya@yahoo.com

(Diterima oleh Dewan Redaksi 10-01-2016)

(Dipublikasikan oleh Dewan Redaksi 01-06-2016)

\begin{abstract}
This study aims to determine how the application of a recruitment and selection of employees in BRI Sharia and how practices are applied in BRI Sharia. Recruitment is the process of finding and attract applicants who have the expertise to occupy certain positions in the organization. Selection is a process to screen applicants become candidates in accordance with the existing selection criteria. This study uses a qualitative method where data collection using observation, interviews, documentation. The object of this research is BRI Sharia bank head office. The sample in this study is the Employees Group Head and policy division. The study states that BRI Sharia using two sources, namely internal and external recruitment. The selection proces of employes in BRI Sharia includes verification of aplication administration, interview, test psychological test, medical check-ups, signing a contract and then there are some weaknesses in the recruitment and selection.
\end{abstract}

Keywords : Recruitment, Selection

\section{ABSTRAK}

Penelitian ini bertujuan untuk mengetahui bagaimana penerapan pola rekrutmen dan seleksi karyawan di BRI Syariah dan bagaimana praktek-praktek yang diterapkan di BRI Syariah. Penelitian ini menggunakan metode kualitatif dengan pengumpulan data menggunakan observasi, wawancara, dokumentasi. Objek dalam penelitian ini adalah bank BRI Syariah Kantor Pusat. Sampel dalam penelitian ini adalah Karyawan divisi Grup Head and policy. Hasil penelitian menyatakan bahwa BRI Syariah menggunakan dua sumber rekrutmen yaitu internal dan eksternal. Untuk seleksi karyawan di BRI Syariah di antaranya yaitu seleksi administrasi lamaran, wawancara, tes psikotes, medical check up, penandatanganan kontrak, kemudian ada beberapa kelemahan-kelemahan dari rekrutmen dan seleksi tersebut.

Nur Rohmatin. 2015. Analisis Pola Rekrutmen dan Seleksi Karyawan di Bank Syariah (Studi pada BRI Syariah Kantor Pusat Jakarta) 145-159 


\section{PENDAHULUAN}

Manajemen sumber daya insani mempunyai peran penting dalam perkembangan perbankan syariah pada saat ini dan yang akan datang, oleh sebab itu dalam memilih sumber daya insani harus lebih profesional, sehingga peranannya dalam mengembangkan industri perbankan syariah akan semakin optimal. Oleh karena itu memberikan kriteria khusus dalam memilih sumber daya insani baikmelalui rekrutmen dan seleksi karyawan. Melihat perkembangan bank syariah saat ini yang masih belum optima., Menurut Amalia dan Al Arif dalam Nurul Istikhomah, Ngadiman dan Shohidin (2014: 112-113) Terkait dengan masalah sumber daya insani (SDI), menyatakan dalam hasil riset penelitian yang telah dilakukan oleh Universitas Indonesia mengungkapkan bahwa SDM bank syariah di Indonesia lebih dari 90\% tidak memiliki latar belakang pendidikan ekonomi syariah. Kemudian, berdasarkan penyampaian Outlook Perbankan Syariah tahun 2007 diketahui bahwa kendala percepatan market share (5\%) perbankan syariah karena faktor SDI, baik yang disebabkan karenaminimnya jumlah SDI perbankan syariah maupun kualitasnya yang masih rendah.

Dari data tersebut untuk mengatasi masalah sumber daya insani, seharusnya bank syariah bekerja sama dengan lembaga pendidikan untuk meminimalisir karyawannya yang masih mempunyai background konvensional yang masih minim dengan pengetahuan keIslamannya. dengan sumber daya insani yang handal dan cerdas baik spiritual maupun intelektual, apabila hal ini dibiarkan, maka tidak menutup kemungkinan dalam perjalanannya perbankan syariah yang akan datang akan mengalami berbagai masalah.

Tantangan yang terjadi dalam industri perbankan syariah saat ini adalah kurangnya sumber daya insani yang berkualitas dan profesional. Sumber daya insani di bank syariah selain harus mampu menguasai operasional banking tetapi juga harus menguasai aspek sisi syariahnya, sebagai landasan Al-Qur'an dan Hadist. Oleh karenanya ada beberapa beberapa tahapan dalam merekrut dan menyeleksi karyawan di Bank Syariah salah satunya ada tes baca Al-Qur'an.

Melakukan proses tahapan-tahapan dalam perekrutan dan penyeleksian tentunya akan mendapatkan sumber daya insani yang berkualitas sesuai dengan kualifikasi yang dibutuhkan oleh perusahaan yang mampu mengelola dan berkomitmen tinggi terhadap visi dan misi bank syariah. Untuk memilih sumber daya insani yang benar-benar profesional dan berkualitas seperti yang diinginkan oleh bank bukanlah perkara mudah, banyak hal yang harus dilakukan. Oleh karena itu, karyawan yang akan diterima bank syariahharus memiliki kompetensi yang sesuai dengan bidang yang diinginkannya.

Berdasarkan uraian diatas, maka mucullah pertanyaan : Bagaimana Pola Rekrutmen dan Seleksi Karyawan Di Bank Syariah? (Studi di BRI Syariah Kantor Pusat Jakarta).

\section{MATERI DAN METODE}

\section{Jenis Dan Obyek Penelitian}

Metode ini merupakan Penelitian deskriptif kualitatif merupakan bagian dari penelitian kualitatif. Deskriptif kualitatif merupakan metode yang digunakan untuk membedah suatu fenomena di lapangan. Penelitian deskriptif kualitatif adalah metode yang menggambarkan dan menjabarkan temuan di lapangan. Metode deskriptif kualitatif hanyalah memaparkan situasi atau peristiwa. Penelitian dengan metode ini tidak mencari atau menjelaskan hubungan, tidak menguji hipotesis atau membuat prediksi. Metode penelitian deskriptif mempunyai dua ciri pokok yaitu:

1. Memusatkan perhatian pada masalahmasalah yang ada pada saat penelitian 
dilakukan (saat sekarang) atau masalah bersifat aktual.

2. Menggambarkan fakta-fakta tentang masalah yang diselidiki bagaimana adanya diiringi dengan interpretasi rasional (Hidayat, 2011: 34).

\section{Sumber data}

\section{Data primer}

Data yang diperoleh secara langsung dengan penelitian melalui wawancara mendalam dengan bagian Human Resource Development (HRD) dan pengamatan langsung serta peneliti terlibat. Dalam penelitian ini pemilihan narasumber menggunakan teknik purposive sampling. Purposive sampling yaitu penentuan sampel berdasarkan tujuan tertentu dengan syarat-syarat yang harus dipenuhi diantaranya:

a. Pengambilan sampel harus didasarkan atas ciri-ciri sifat atau karakteristik tertentu, yang merupakan ciri-ciri pokok populasi.

b. Subjek yang diambil sebagai sampel benar-benar merupakan subjek yang paling banyak mengandung ciri-ciri yang terdapat pada populasi.

c. Penentuan karakteristik populasi dilakukan dengan cermat didalam studi pendahuluan (Arikunto, 2010: 183).

\section{Data sekunder}

Sumber sekunder adalah sumber data yang diperoleh dengan cara membaca, mempelajari, dan memahami melalui media lain yang bersumber dari literature (Burhan, 2005: 128). Data sekunder dalam penelitian ini berasal dari berbagai literatur yang berhubungan dengan rekrutmen dan seleksi karyawan.

\section{Populasi Dan Sampel}

\section{Populasi}

Populasi adalah wilayah generalisasi terdiri atas obyek/subyek yang mempunyai kualitas dan karakteristik tertentu, ditetapkan oleh peneliti untuk dipelajari dan kemudian ditarik kesimpulannnya (Sugiono, 2010: 115). Berdasarkan pengertian tersebut, maka dalam penelitian ini populasinya adalah bank syariah.

\section{Sampel penelitian}

Sampel adalah kelompok kecil yang diamati dan merupakan bagian dari populasi sehingga sifat dan karakteristik populasi juga memiliki oleh sampel. Ferguson mendefinisikan sampel adalah beberapa bagian kecil atau cuplikan yang ditarik dari populasi (Sedarmayanti, 2011: 124). Adapun sampel dari penelitian ini adalah Bank BRI syariah.

\section{Teknik Pengumpulan Data}

\section{Observasi}

Penelitian dengan pendekatan kualitatif ini adalah salah satu metode dalam pengumpulan data. Observasi merupakan satu cara untuk mengumpulkan data penelitian. Menurut Parsudi maupun Adler dalam (Denzin, 1994: 378). Kemungkinan observasi atau pengamatan dianggap suatu teknik atau metode yang mudah padahal apabila observasi atau pengamatan ini dilakukan dengan baik dan cermat dan disertai dengan peneliti yang mempunyai atau menguasai atau menguasai teori yang cukup banyak, maka teknik ini dapat memberi gambaran kondisi yang memuaskan, artinya memberigambaran yang menyeluruh apa adanya.

\section{Wawancara}

Dalam penelitian ini mengajukan pertanyaan kepada divisi Human Capital policy and evaluation departmen Head BRI syariah Mengenai rekrutmen dan seleksi karyawan di BRI Syariah dalam memilih karyawan, untuk mendapat jawaban yang benar merupakan pekerjaan yang cukup sulit, wawancara merupakan cara yang umum dan ampuh untuk memahami suatu keinginan atau kebutuhan. 


\section{Catatan lapangan}

Catatan lapangan sangat diperlukan dalam penelitian kualitatif sebab catatan lapangan merupakan gambaran yang orisinil dari hasil penelitian, dan kegunaan catatan lapangan ini. Menurut Bodgan dan Biklen dalam (Moleong, 1997: 153) adalah bahwa suatu catatan yang tertulis merupakan suatu yang didengar dan dilihat, dialami, dan dipikirkan dalam rangka pengumpulan data dan refleksi terhadap data dalam penelitian kualitatif.

\section{Dokumentasi}

Dokumen merupakan salah satu alat yang digunakan untuk mengumpulkan data dalam penelitian kualitatif. Dokumen adalah catatan tertulis yang isinya merupakan setiap pernyataan tertulis yang disusun oleh seseorang atau lembaga untuk keperluan pengujian suatu peristiwa.

\section{Teknik Analisis Data}

\section{Triangulasi}

Triangulasi adalah teknik pemeriksaan keabsahan data yang memanfaatkan sesuatu yang lain di luar data sebagai pembanding terhadap data tersebut. Terdapat tiga macam triangulasi yaitu triangulasi dengan sumber, triangulasi dengan teknik, dan triangulasi waktu. Pada penelitian ini penulis menggunakan triangulasi dengan menggunakan sumber yaitu dengan cara mengecek data yang diperoleh melalui beberapa sumber. Dalam penelitian ini untuk menguji kredibilitas data pemanfaatan koleksi $e$-book, maka data yang diperoleh diujikan kepada pemustaka yang merupakan subyek dari penelitian serta disesuaikan dengan teori-teori yang ada (Moleong, 2002: 326). Dengan ini peneliti menggunakan 3 sumber diantaranya buku-buku, dokumen-dokumen yang mengenai perekrutan dan seleksi karyawan dari Bank BRI Syariah, dan buku-buku yang berhubungan dengan rekrutmen dan seleksi karyawan.

\section{Reduksi}

Reduksi yaitu merangkum, memilih halhal pokok, dan memusatkan pada hal-hal penting. Dengan begitu, data yang direduksi akan memberikan gambaran yang lebih jelas. Dalam penelitian ini, peneliti memfokuskan pada pemanfaatan koleksi buku yang dilakukan pemustaka.

\section{Penyajian Data}

Setelah data yang diperoleh tersebut direduksi, langkah berikutnya adalah menyajikan data. Data disajikan dalam bentuk teks yang bersifat naratif dan mengelompokkan sesuai dengan sub bab masing-masing.

\section{Penarikan Kesimpulan}

Setelah data disajikan, langkah selanjutnya yaitu penarikan kesimpulan. Setelah menjelaskan berbagai data yang telah diperoleh, peneliti membuat kesimpulan yang merupakan hasil dari suatu penelitian (Sugiyono, 2013: 247). Setelah melakukan rangkaian beberapa metode dan analisis yang digunakan, sehingga dari penelitian ini bisa ditarik kesimpulan dari hasil penelitian berupa proses rekrutmen dan seleksi karyawan di BRI Syariah .

\section{HASIL DAN PEMBAHASAN}

1. Pola Rekrutmen di BRI Syariah

Data hasil interview dengan Bapak Rusdi Musa Ishaq Divisi Human Capital Policy and Evaluatin Departemen Headyang peneliti lakukan di BRI Syariah . Rekrutmen ini sepenuhnya dilakukan oleh divisi rekrutmen dan seleksi, rekrutmen ini dilaksanakan untuk mendapatkan karyawan baru untuk menempati jabatan kosong yang ada diBRI Syariah . Jika di BRI Syariah ada jabatan yang kosong perusahaan langsung menghubungi divisi rekrutmen untuk membuka lowongan dan memproses surat lamaran yang diajukan pelamar di BRI Syariah, kemudian diseleksi oleh divisi rekrutmen dan seleksi. 
Proses rekrutmen dilakukan dengan mencari sumber-sumber tenaga kerja yang berasal dari internal perusahaan maupun eksternal perusahaan (Fahmi dkk, 2014: 160). Hal ini selaras dengan proses rekrutmen di BRI Syariah ada yang juga berasal dari sumber internal dan eksternal. Proses rekrutmen yang dilakukan di BRI Syariah divisi rekrutmen dan seleksi yaitu menentukan sumber atau metode perekrutan, sumber perekrutan yang diterapkan oleh BRI Syariah ada dua diantaranya sumber internal dan sumber eksternal.

\section{a. Sumber internal}

Rekrutmen dari internal perusahaan dapat memberikan kesempatan kepada para karyawan untuk meniti karir lebih lanjut kejabatan diatasnya, sehingga dapat menimbulkan gairah motivasi. BRI Syariah merekrut karyawan dari sumber internal atau dari dalam perusahaan sendiri, misalnya perusahaan membutuhkan bagian Supervisor pelayanan kas di Kantor Cabang, pada saat itu karyawan bagian supervisor pelayanan kas mengundurkan diri, bagian unit Head akan mengumumkan kepada seluruh karyawan BRI Syariah melalui Email, bahwa perusahaan BRI Syariah membutuhkan supervisor pelayanan kas, dan siapa yang memenuhi syarat sebagai berikut :

1) Berpengalaman diBRI selama 2 tahun.

2) Berpengalaman dalambidang supervisor pelayanan kas.

3) Performance Appraisal (penilaian Kerja) adalah kegiatan penilaian prestasi atau kinerja yang menuju pada penilaian mengenai prestasi masa lalu dan masa kini terhadap seseorang berdasarkan lingkungan pekerjaannya dan potensi masa depannya bagi organisasi. Penilaian personil harus berdasarkan kepada partisipasi individu dan perannya yang dikaitkan dengan kegiatan supervisi:

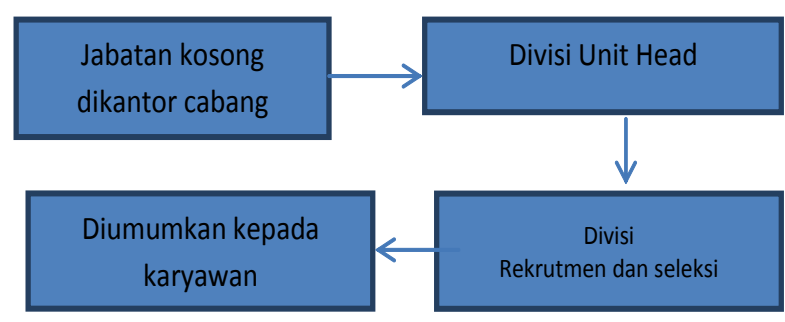

Gambar 1. Alur rekrutmen

Sumber : Dari berbagai Sumber

\section{b. Sumber Eksternal}

Sumber eksternal yaitu tenaga kerja yang direkrut orang-orang yang belum menjadi karyawan suatu perusahaan atau lembaga oraganisasi. Penentuan untuk jabatan kosong di BRI Syariah , untuk sumber eksternal misalnya ada karyawan yang mengundurkan diri, sehingga pemimpin cabang harus menghubungi wilayah terlebih dahulu, setelah itu wilayah menghubungi divisi grup headpusat, sehingga kepala divisi langsung mengkonfirmasi dan membuat kualifikasi atau persyaratan jabatan yang kosong. Untuk kualifikasi atau persyaratan dari sumber eksternal diantaranya:

1) Pria/wanita dari negara Indonesia

2) Usia maksimal 25 tahun untuk fresh graduate atau 35 tahun untuk yang sudah berpengalaman bekerja.

3) Untuk pendidikan S1 semua jurusan (non pendidikan) dari universitas yang berakreditasi.

4) IPK minimal 2.75 dari skala 4,0

5) Berpenampilan menarik, tidak buta warna, dapat berkomunikasi dengan baik.

Bagi siapa yang berminat dan memenuhi syarat silahkan mengirimkan lamaran dengan melampirkan :

1) Surat lamaran 
2) Curiculum vitae

3) Foto copy ijazah terakhir, foto copy KTP, Foto copy transkip nilai

4) Surat keterangan sehat dari dokter

5) SKCK

6) Foto $4 \times 6$

Setelah menentukan persyaratan jabatan BRI Syariah mengumumkan melalui website maupun dalam merekrut karyawannya dari sumber eksternal mengikuti job fairdan bekerja sama dengan kampus, seperti yang dilakukan BRI Syariah awal Agustus ini akan diadakan job fair via Universitas Gajah Mada, dan mengadakan seminar-seminar, iklan, jasa Outsouching

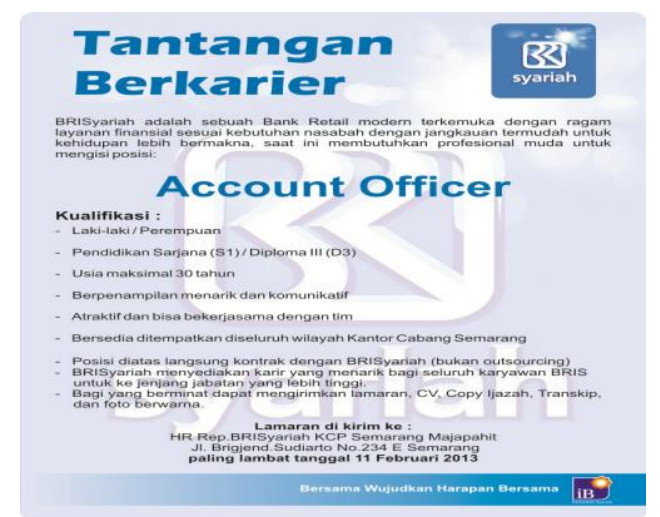

Gambar 2 Iklan lowongan pekerjaan

Sumber : BRI Syariah

Dengan semakin berkembangnya perusahaan, bank BRI Syariah terus melakukan rekrutmen pegawai. Ada 3 jalur perekrutan karyawan di bank BRI Syariah yaitu:

1) Jalur Officer Development Program (ODP) yaitu merekrut calon karyawan dari fresh graduateyang diposisikan sebagai tenaga marketing dan langsung ikatan dinas dengan BRI Syariah . Apabila dalam dua tahun kinerja karyawan bagus maka akan dinaikan jabatanya sebagai karyawan tetap. Karyawan dari Officer Development Program (ODP) juga disiapkan untuk menjadi pemimpin bank syariah.
2) Special Hire, yaitu merekrut calon karyawan yang berpengalaman untuk mengisi jabatan yang dibutuhkan perusahaan. Apabila dalam satu tahun kinerja karyawan menunjukan kinerja yang baik maka akan diangkat sebagai karyawan tetap. Hal tersebut selaras dengan firman Allah SWT (Q.S Yusuf :55)

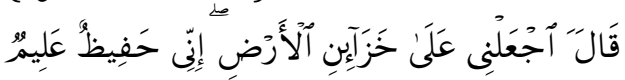

Artinya : "Berkata Yusuf: "Jadikanlah aku bendaharawan negara (Mesir); Sesungguhnya aku adalah orang yang pandai menjaga, lagi berpengetahuan"

Menurut ahli tafsir, jabatan yang akan diduduki yusuf adalah bendahara keuangan negara. Dan ayat tersebut juga mengisyaratkan bahwa calon tenaga kerja yang akan menduduki jabatan tertentu harus memenuhi syarat-syarat yang telah ditetapkan(Salam, 2014: 110).

3) Jalur outsourching yaitu merekrut karyawan yang diposisikan untuk tenaga kerja frontliner. Dalam hal ini bank BRI Syariah bekerja sama dengan vendor outsourching. Apabila dalam satu tahun karyawan menunjukan kinerja yang baik, maka karyawan bisa dikontrak langsung oleh bank BRI Syariah hingga mendapatkan kesempatan untuk menjadi karyawan tetap.

\section{Pola Seleksi di BRI Syariah}

Setelah proses rekrutmen selesai dilakukan, maka tahap berikutnya adalah proses seleksi. Proses seleksi adalah proses pemulihan kandidatkandidat yang telah terkumpul untuk mengisi suatu posisi atau pekerjaan di dalam organisasi yang dianggap memenuhi kualifikasi dan kompetensi yang dibutuhkan. Proses seleksi ini dilakukan ketika kandidat-kandidat terbaik telah dikumpulkan (pool of Talent) dan kemudian dipilihyang paling baik. Keputusan untuk memilih kandidat didasarkan pada beberapa kriteria yang 
telah sebelumnya(Hanggraeni, 2012:63).

Seleksi yang dilaksanakan BRI Syariah dalam menyeleksi calon karyawan ada beberapa proses tahapan. Dalam praktek jenis seleksi karyawan antara rekrutmen internal dengan rekrutmen eksternalnya berbeda. Jika dilihat berdasarkan prosedur rekrutmen eksternal BRI Syariah, setelah lolos seleksi administrasi maka karyawan eksternal akan langsung tahap psikotes, interview dan tes kesehatan. Untuk seleksi dari internal ada interview dan asessment.

\section{a. Seleksi karyawan dari sumber eksternal}

Seleksi yang diterapkan diBRI Syariah dari sumber eksternal diantaranya:

1) Seleksi Administrasi lamaran

Seleksi administrasi ini dilakukan untuk mendapatkan kandidat yang sesuai dengan kualifikasi yang ditetapkan BRI Syariah terhadap deskripsi pekerjaan tertentu. Dalam melakukan shortir data pelamar divisi rekrutmen dan seleksi karyawan di BRI Syariah sangat teliti, sehingga calon karyawan harus memberikan informasi yang selengkaplengkapnya diantaranya:

a) Identitas pelamar (nama, jenis kelamin, umur ,agama, status, keluarga, alamat, nomor telpon yang bisa dihubungi dan sebagainya.

b) Riwayat pendidikan (jenjang pendidikan, kursus-kursus pelatihan-pelatihan yang pernah diikuti dan prestasi yang pernah dicapai.

c) Riwayat pekerjaan dan pengalaman kerja, calon karyawan pernah memiliki pengalaman kerja sebelumnya, berapa lama dan apa jabatanya.

d) Kegiatan-kegiatan diluar pekerjaan/pendidikan (hobi, apa yang dilakukan pada waktu luang dan pengalaman organisasi.

e) Surat refrensi termasuk ijazah sekolah, surat keterangan kerja, surat rekomendasi

Divisi rekrutmen dan seleksi karyawan di BRI Syariah akan menganalisis data-data pelamar, Curiculum Vitae dari calon karyawan yang memenuhi syarat sesuai klasifikasi yang telah ditentukan oleh BRI Syariah . Jika ada salah satu data pelamar yang kurang lengkap tidak lolos untuk tahapan tes selanjutnya.

2) Seleksi Interview

Tujuan interviewyang dilakukan di BRI Syariah untuk mengenal lebih dekat dengan calon karyawan. Dalam interview ini ada beberapa aspek yang di tanyakan kepada calon karyawan saat interview, mulai dari aspek syariah, aspek pengetahuan, aspek perilaku. Untuk aspek syariah karyawan ada tes baca Al-Qur'andan mengenai pengetahuan Agama, dari aspek pengetahuan apa saja yang dikuasai oleh calon karyawan misalnya bidang IT kinerja apa yang telah dicapai, prestasi yang telah didapatkan. Sedangkan untuk aspek perilaku, apakah seorang calon karyawan tersebut merokok, tindik maupun bertato karenaperaturan baru di BRI Syariah tidak boleh merokok maupun juga bertindik. Hal ini sesuai apa yang Allah SWT Firmankan dalam (QS An-Nisa ayat: 119)

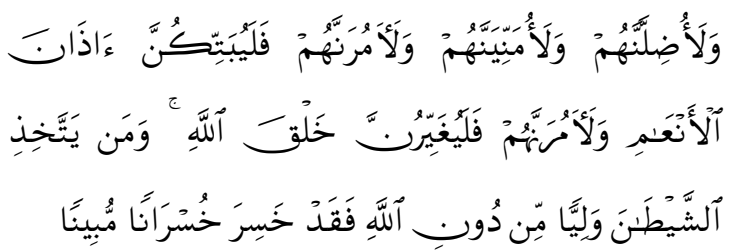

Artinya "Dan aku benar-benar akan menyesatkan mereka, dan akan membangkitkan angan-angan kosong pada mereka dan menyuruh mereka (memotong telinga-telinga binatang ternak), lalu mereka benar-benar memotongnya, dan akan aku suruh 
mereka (mengubah ciptaan Allah), lalu benar-benar mereka merubahnya". Barangsiapa yang menjadikan syaitan menjadi pelindung selain Allah, Maka Sesungguhnya ia menderita kerugian yang nyata".

Ayat tersebut menjelakan Merubah ciptaan Allah SWT dapat berarti, mengubah yang diciptakan Allah SWT seperti mengebiri binatang. ada yang mengartikannya dengan merubah agama Allah SWT. Oleh karena itu Allah SWT melarang umatnya untuk memakai tato ataupun tindik.

3) Tes Psikotes

Jenis tes psikotes yang dilakukan BRI Syariah seperti yang dikutip dalam buku manajemen sumber daya manusia (Hanggraini, 2012: 70-71):

a) Tes IQ

Tes kecerdasan ini melibatkan

serangkaian soal matematika yang berbentuk tes verbal dan nonverbal. Angka dan bahasa merupakan bagian dari tes ini. Seperti jika anda senang dengan teka teki silang dan hitungan secara cepat maka anda beruntung bisa lulus. Namun tes IQ memang dibuat standar agar bisa dilakukan.

b) Tes Kepribadian

Padates ini calon karyawan dihadapkan kepada sejumlah pertanyaan yang mengenai berbagai permasalahan dalam pekerjaanya seperti bagaimana menghadapi konflik, bagaimana bekerjasama dan seberapa jauh kemampuan anda bekerja dalam tim apakah anda termasuk orang-orang yang hangat dalam pergaulan dan tidak kaku.

c) Tes Kemampuan

Dalam tes kemampuan akan diuji serangkaian tugas yang berada tekanan tinggi, apakah anda masih bisa melakukannya. Biasanya tes kemampuan ini mengkondisikan calon karyawan dalam suasana penuh tekanan tetapi harus menyelesaikan soal dengan cepat. Bisa bentuknya angka atau permainan kata-kata, bisa pula berupa grafik dan bentuk-bentuk ketiga dimensi. d) Tes Kreativitas

Biasanya dalam tes ini calon karyawan akan diminta menulis atau menggambarkan sesuatu. Pada salah suatu tes calon karyawan diminta melanjutkan gambar dari enam kotak yang sudah ada. Lanjutkan dengan ilustrasi yang baik semaksimal mungkin. Satu lagi tes final biasanya calon karyawan diminta menggambar.

e) Tes Kesehatan (Medical)

Setelah poin 1,2 dan 3 sudah lulus, untuk tahapan 4 yaitu medical ceck up, ini dilakukan kepada calon karyawan yang sudah lolos tahap ke3, medical ceck up ini BRI Syariah bekerjasama dengan lembaga kesehatan yang ditunjuk untuk memeriksa calon-calon karyawan. Ada beberapa pemeriksaan diantarannya pemeriksaan urin untuk memastikan karyawan tersebut tidak mengidap penyakit dalam seperti diabetes dan untuk mengetahui calon karyawan tersebut menggunakan obat-obatan terlarang seperti narkoba apa tidak. Firman Allah SWT Q.S An-Nisa ayat 43 larangan mengunakan narkoba:

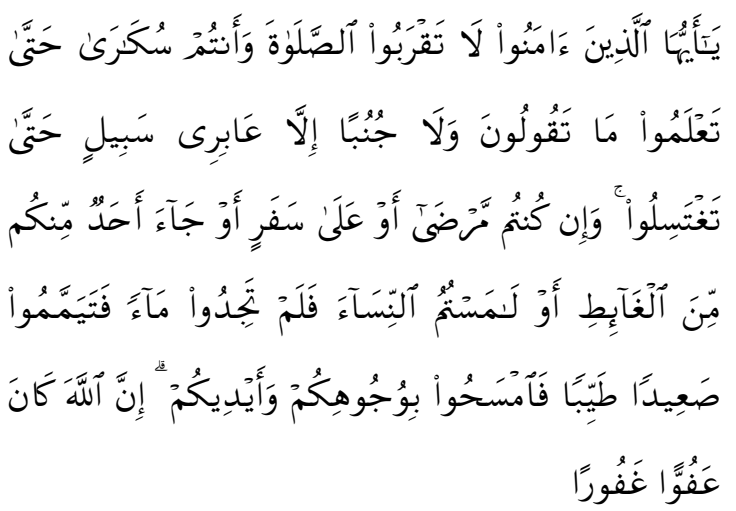

Artniya : "Hai orang-orang yang beriman, janganlah kamu shalat, sedang kamu dalam Keadaan mabuk, sehingga kamu mengerti apa yang kamu ucapkan.

Ayat tersebut mengungkapkan bahwa larangan untuk mengkonsumsi hal-hal yang memabukkan seperti narkoba dan barang lainnya yang memabukkan. Jika orang suka 
mengkonsumsi narkoba akan mengganggu dalam kinerja di perusahaan. Sehingga BRI Syariah tidak memilih orangyangmengkonsumsi narkoba.

Pemeriksaan darah ini dilakukan karena mengantisipasi dikhawatirkan ada calon karyawan yang terkena HIV/AIDS, sekaligus bagi calon karyawan laki-laki apakah perokok berat apa tidak. Larangan merokok dalam firman Allah SWT dalam (Q.S. Al-A'raf ayat 157)

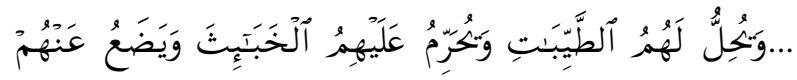

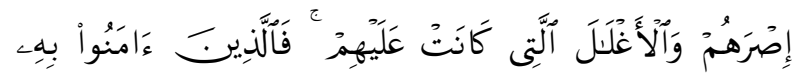

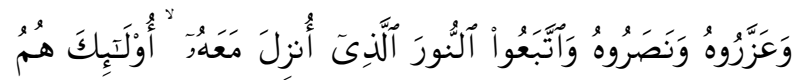

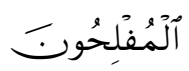

Artniya :"menghalalkan bagi mereka Segala benda yang baik, dan mengharamkan kepada mereka Segala benda yang buruk; dan ia juga menghapuskan dari mereka beban-beban dan belenggu-belenggu yang ada pada pada mereka.

Ayat tersebut dapat diketahui bahawa Allah SWT mengharamkan yang buruk bagi seseorang, dalam hal ini adalah karyawan. Dikarenakan merokok tersebut akan berdampak buruk dan berbahaya bagi diri seorang karyawan dan akan menggangu situasi pekerjaan yang tidak nyaman. Sehingga BRI Syariah tidak akan memilih orang yang merokok, dikhawatirkan akan menggangu lingkungan pekerjaan. Pemeriksaan mata dilakukan karena untuk mengetahui apakah calon karyawan tersebut rabun jauh atau buta warna.

4) Penandatanganan kontrak

Proses seleksi terakhir dari sumber eksternal di BRI Syariah adalah penandatangan kontak, jika karyawan tersebut langsung jadi karyawan kontrak, calon karyawan tersebut akan menandatangani PKWT (Perjanjian Kerja Waktu Tertentu). Dan jika calon karyawan tersebut karyawan tetap akan menandatangani

PKWTT

(Penandatangan Kerja Waktu Tidak Tertentu) yaitu, perjanjian kerja antara pekerja/buruh dengan pengusaha untuk mengadakan hubungan kerja yang bersifat tetap. Pekerjanya sering disebut karyawan tetap.

Penandatangan kontrak merupakan salah satu bentuk kerja sama yang dilakukan BRI Syariah kepada karyawannya. Sehingga dengan adanya kerja sama ini akan menguntungkan bagi karyawan maupun perusahaan dalam hal ini adalah BRI Syariah. Perusahaan tidak mungkin untuk mengerjakan sendiri tanpa bekerja sama, dan tidak mungkin karyawan bekerja tanpa adanya perusahaan. Setelah perjanjian/ kontrak penandatangan setelah terjadi kewajiban perusahaan kepada karyawannya, memberikan upah yang layak, menyediakan tempat kerja, memberikan kenyamanan kepada karyawannya, meningkatkan kecakapan dan keterampilan pekerja, mengembangkan kepribadian pekerja, membantu karyawan untuk sukses dan memberi penghargaan atas prestasi serta tunjangan sosial dan pesangon.Firman Allah SWT Q.S.AlMaidah ayat 1:

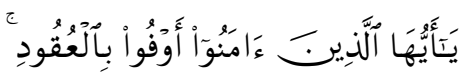

Artinya :"Hai orang-orang yang beriman, penuhilah aqad-aqad itu"

Ayat di atas menjelaskan bahwa Allah SWT menyuruh agar hambahambaNya memenuhi janji terhadap Allah SWT dan perjanjian-perjanjian yang mereka buat sesamanya.

\section{b. Seleksi karyawan dari sumber internal}

Seleksi yang diterapkan di BRI Syariah dari sumber internal tidak lagi melakukan pemeriksaan medical ceck up. Sehingga dalam seleksi karyawan dari sumber intenal ini hanya tes interview dan assesment (jika naik jabatan): 
1) Seleksi administrasi

Seleksi admisitrasi dari sumber internal untuk memperkuat data calon karyawan, karena sudah teruji dengan kemampuan yang dimiliki saat bekerja.

2) Interview

Interview lebih mendalam dan untuk mengenal karyawan lebih dekat dengan calon karyawan. Dikarenakan dalam rekrutmen dari sumber internal merupakan dari karyawanya sendiri. Sehingga Divisi rekrutmen akan lebih mudah menanyakan mengenai pengetahuan dimiliki calon karyawan.

3) Psikotes

Psikotes ini juga dilakukan pada calon karyawan dari sumber internal maupun eksternal, tujuannya adalah melihat karakter seseorang, namun dalam tes psikotes tidak terdapat kategori lulus atau tidak lulus, misalnya pelamar memiliki karakter ceroboh, tentu tidak cocok dan sesuai dalam pekerjaan yang membutuhkan ketelitian. Namun, ada pula kasus dimana pelamar memiliki kualitas yang jauh melampaui pekerjaan yang dia tuju. Bisa jadi proses penerimaan dihentikan karena posisi yang tersedia terlalu rendah untuk pelamar tersebut. Sehingga setiap calon karyawan yang akan masuk di BRI Syariah akan mengikuti psikotes.

4) Asessment

Dengan menggunakan metode assesment memberikan manfaat kepada perusahaan terutama pada BRI Syariah dan karyawan. Bagi BRI Syariah sendiri akan mendapatkan efek dari pengembangan karir pada karyawannya dari segi produktivitasnya dan juga kinerja untuk bank BRI Syariah itu sendiri. Sedangkan untuk karyawan BRI Syariah sendiri karyawan akan mengetahui kelemahan dan kekuatan kinerjanya. Hal tersebut perlu dikembangkan sehingga akan memberikan kesempatan pada karyawan untuk tumbuh dan berkembang, serta memberikan semangat di dalam melaksanakan tugasnya.

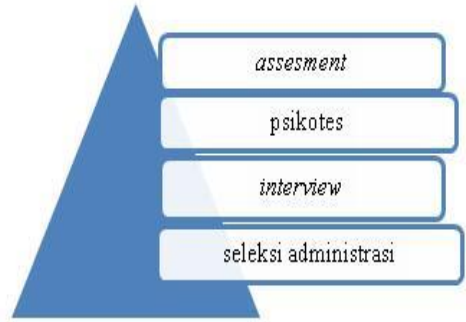

Gambar 3 Proses seleksi dari sumber internal

Sumber. Dari berbagai sumber

\section{c. Kriteria penilaian dalam seleksi}

Proses seleksi di BRI Syariah ada beberapa faktor menjadi bahan penilaian di BRI Syariah, apakah calon karyawan tersebut masuk dalam kualifikasi yang dipersyaratkan apa tidak, seperti untuk jenjang fresh graduate S1 maupun S2 dilihat dari IPK minimal 2.75 baik dari Universitas Swasta dan Universitas Negeri. Untuk batasan usia untuk S1 adalah 25 tahun sedangkan untuk S2 batasan usianya 35 tahun. Pengalaman yang dimiliki dalam bekerja, kemampuan dibidang akademik, hasil tes psikotesnya baik, hasil medical check up-nya baik, akan masuk menjadi karyawan di BRI Syariah . (Firman Allah SWT Q.S AlBaqarah ayat 247):

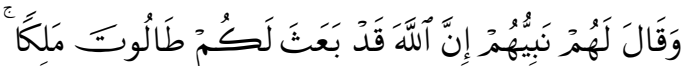

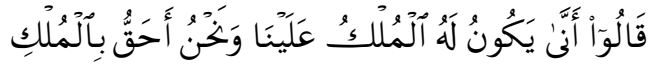

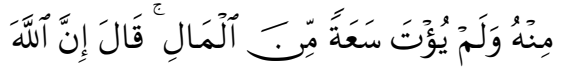

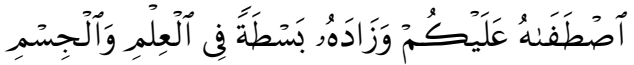

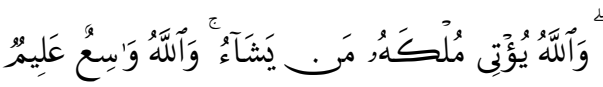

Artniya : "Nabi mereka mengatakan kepada mereka: "Sesungguhnya Allah telah mengangkat Thalut menjadi rajamu." mereka menjawab: 
"Bagaimana Thalut memerintah Kami, Padahal Kami lebih berhak mengendalikan pemerintahan daripadanya, sedang diapun tidak diberi kekayaan yang cukup banyak?" Nabi (mereka) berkata: "Sesungguhnya Allah telah memilih rajamu dan menganugerahinya ilmu yang Luas dan tubuh yang perkasa." Allah memberikan pemerintahan kepada siapa yang dikehendaki-Nya. dan Allah Maha Luas pemberian-Nya lagi Maha mengetahui"

Ayat tersebut mengisahkan bahwa Allah SWT telah mengutus seorang raja kepada mereka yang bernama Thalut. Thalut adalah seorang prajurit, bukan dari kalangan istana atau keturunan raja mereka.Oleh karena itu, Bani Israil menolaknya, mereka berpandangan bahwa, mereka lebih berhak menjadi raja dibanding Thalut, karena Thalut tidak memiliki kekayaan tetapi Allah SWT mengangkat Thalut karena dia memiliki ilmu yang lebih dibanding yang lain mereka Thalut lebih cerdas, tubuhnya lebih kekar, lebih kuat, sabar menghadapi peperangan, serta menguasai taktik dan strategi perang.

Dengan menghubungkan pernyataan diatas dalam analisis kebutuhan yang dilakukan dalam perencanaan karyawan merupakan dasar aktifitas pengelolaan tenaga kependidikan lainnya, termasuk dalam penempatan pegawai. Allah SWT menempatkan Adam sebagai Khalifah dibumi didasarkan adanya kebutuhan tenaga yang mampu mengemban amanat kekhalifahan dimuka bumi (Salam, 2014: 140).

Untuk calon karyawan eksternal di BRI Syariah kriteria penilaiannya yaitu melengkapi data-data yang selengkap-lengkapnya mengenai data diri calon karyawan. Dari latar belakangnya, dari pengalaman kerja sebelumnya, psikotesnya, saat interview, medical check up, sehingga perusahaan mendapatkan memperoleh calon karyawan yang benar ideal sesuai kebutuhan.

Seperti yangdilakukan Rasullulah Saw selektif dalam memilih pegawainya, yaitu mereka yang agamanya kuat dan merupakan pioneer dalam masuk agama Islam. Rasullulah Saw meminta pendapat para sahabat tentang track recordataupun kepribadian calon pegawai. Rasullulah Saw pernah mencopot dan melengserkan pegawainya 'Ala' bin Al-Hadahrani di Bahrain, karena ada laporan dari utusan Abdul Qais, dan menggantinya dengan Aban bin Saad (Salam, 2014: 124).

d. Hambatan-Hambatan seleksi yang dihadapi BRI Syariah

Hambatan-hambatan seleksi yang ada di bank BRI Syariah untuk mendapatkan karyawan yang kualitas baik, dan biasanya karyawan yang kualitas baik tersebut itu sudah melamar ke bank yang lebih tinggi yaitu bank syariah yang mempunyai aset yanglebih banyak dan bank tersebut sudah banyak mendapatkan penghargaan-penghargaan menjadi bank terbaik.

Sehingga BRI Syariah cukup sulit bersaing dengan bank syariah lain untuk mendapatkan lulusan yang terbaik. Akan tetapi biasanya untuk Divisi Officer Development Program (ODP)rata-rata BRI Syariah memilih kandidat yang lulusan Universitas ternama misalnya dari lulusan UGM, dan untuk bagian pelaksana BRI Syariah mengambil lulusan minimal kampusyang terakreditasi baik.

Hambatan-hambatan seleksi di BRI Syariah selanjutnya yaitu mendapatkan karyawan-karyawan yang mempunyai latar belakang dan dasar perbankan syariah. Sehingga BRI Syariah memilih karyawan yang selain ekonomi Islam. 
3. Kelemahan dan Kekuatan Rekrutmen dan Seleksi di BRI Syariah

a. Kelemahan rekrutmen di BRI Syariah

Kelemahan-kelemahan rekrutmen di BRI Syariah diantaranya:

1) Ketika sumber internal diterapkan di BRI Syariah, hal ini akan mengurangi peluang BRI Syariah untuk mendapatkan calon karyawan yang diinginkan dan sesuai kebutuhan.

2) Jika sumber internal diterapkan otomatis akan ada perpindahan antara divisi satu ke divisi yang lain, sumber internal ini akan berdampak pada pekerjaan yang ditinggalkan sehingga pekerjaan yang ditinggalkan tersebut kosong tidak ada yang menempati. Dan akhirnya BRI Syariah merekrut karyawan baru untuk menempati jabatan kosong tersebut.Sehingga ini tidak efisien dikarenakan selalu menambah biaya dan juga akan menimbulkan lowongan- lowongan yang baru.

3) Kurangbekerjasama dengan lembaga pendidikan sehingga untuk mendapatkan lulusan dari perbankan syariah ini sangat terbatas.

b. Kelemahan seleksi karyawan di BRI Syariah

Kelemahan dalam seleksi di BRI Syariah, melihat metode seleksi yang diterapkan di BRI Syariah ada beberapa tahap, ini akan berakibat pada calon karyawan BRI Syariah sendiri, calon karyawan akan cepat berpindah dengan pekerjaan dengan yang lain. Karena setiap waktu tahapan yang cukup lama sehingga BRI Syariah mempunyai potensi akan kehilangan karyawannya. Karena semakin banyak pelamar akan semakin lama proses atau tahapantahapannya.

Menurut Mardianto seleksi berbasis kompetensi memerlukan waktu yang substansial oleh manajer dan orang-orang yang terlibat dalam kelompok interview dan assesment. Untuk manajer khususnya, sering kali sulit untuk menjadwalkan aktifitas ini (Mardianto,2012: 224) untuk mendapatkan karyawan yang sesuai dengan kebutuhan dan berkompeten, akan membutuhkan waktu yang sangat lama bagi para penyeleksi untuk mendapat karyawan yang terbaik. Dan belum tentu semua kandidat yang melamar di BRI Syariah akan masuk dalam tahap selanjutnya.

c. Kekuatan rekrutmen di BRI Syariah

Kekuatan rekrutmen di BRI Syariah dilihat dari sumber perekrutan yaitu dari sumber eksternal dan sumber internal, kekuatan yang akan dimiliki seorang karyawan dari sumber eksternal yaitu karyawan memiliki gagasan baru atau ide segar dan sudut pandang yang baru, dan bisa membawa wawasanindustri yang baru, sedangkan kekuatan dari sumber internal karyawan yaitu karyawan yang lama telah memahami secara baik kebijakan, prosedur, ketentuan dan kebiasaan berorganisasi.

\section{d. Kekuatan seleksi di BRI Syariah}

Kekuatan seleksi di BRI Syariah adalah tahapan demi tahapan yang dilalui oleh calon karyawan, secara tidak langsung akan menyaring untuk mendapatkan calon karyawan yang berkompeten dan sesuai kebutuhannya. Mulai dari tahap administrasi lamaran, interview, tes psikotes, dan medical check up. Hal ini sependapat dengan Ibnu Taimiyah bahwa metode yang digunakan dengan oleh Nabi Muhammad Saw dalam pemilihan dan pengangkatan para pembantu untuk mengelola pemerintahannya diantaranya harus yang paling layak dan sesuai, memilih individu yang berkualitas terbaik. 
Memilih dan mengangkat pegawai yang benar-benar mumpuni (memenuhi semua kriteria), tidaklah mudah dan bahkan tidak ada dan bila tidak ditemukan figur tanpa cela, harus dipilih secara selektif seseorang yang mempunyai kualitas tinggi dari sejumlah calon yang ada, selanjutnya yaitu memilih individu yang amanah orang yang memiliki sifat quwah sekaligus amanah sangatlah sedikit (Fahmi dkk, 2014:93).

Memilih dengan kriteria amanah karena kejujuran dalam bekerja merupakan hal yang harus dimiliki oleh seorang karyawan diperusahaan. Firman Allah SWT (Q.S Al-Baqarah ayat 283):

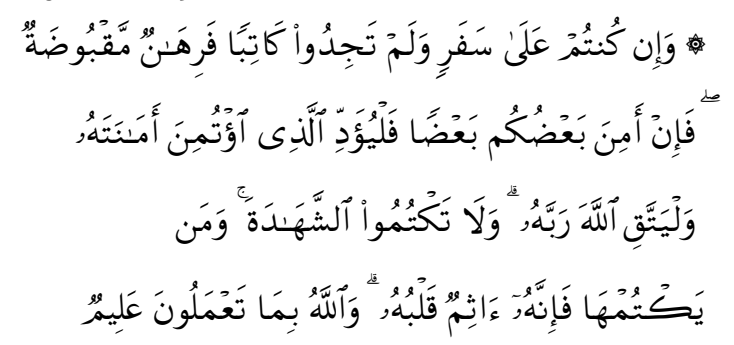

Artinya : "Dan jika kamu berada Dalam musafir (lalu kamu berhutang atau memberi hutang Yang bertempoh), sedang kamu tidak mendapati jurutulis, maka hendaklah diadakan barang gadaian untuk dipegang (oleh orang Yang memberi hutang). kemudian kalau Yang memberi hutang percaya kepada Yang berhutang (dengan tidak payah bersurat, saksi dan barang gadaian), maka hendaklah orang (yang berhutang) Yang dipercayai itu menyempurnakan bayaran hutang Yang diamanahkan kepadaNya, dan hendaklah ia bertaqwa kepada Allah Tuhannya. dan janganlah kamu (Wahai orang-orang Yang menjadi saksi) menyembunyikan perkara Yang dipersaksikan itu. dan sesiapa Yang menyembunyikannya, maka Sesungguhnya ia adalah orang Yang berdosa hatinya. dan (ingatlah), Allah sentiasa mengetahui akan apa Yang kamu kerjakan".

Selain itu di BRI Syariah dengan tahapan-tahapan dan Proses yang sangat ketat demi mendapatkan karyawan yang berkompeten dan mampu memenuhi kebutuhan. dan karyawan tersebut nantinya akan dipekerjakan yang sesuai dengan kualifikasi yang telah ditentukan oleh BRI Syariah . Firman Allah SWT dalam (Q.S. Al-Baqarah: 129)

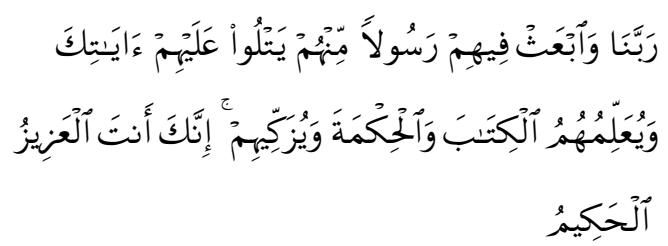

Artinya: "Wahai Tuhan kami! Utuslah kepada mereka seorang Rasul dari kalangan mereka sendiri, yang akan membacakan kepada mereka ayatayat (firmanMu) dan mengajarkan mereka isi kandungan Kitab (AlQuran) serta hikmat kebijaksanaan dan membersihkan (hati dan jiwa) mereka (dari syirik dan maksiat). Sesungguhnya Engkaulah Yang Maha Kuasa, lagi Maha Bijaksana".

Ayat tersebut mengungkapkan bahwa mengutus seseorang yang tepat dan harus pada pengetahuan dan pengalamannya, sehingga tidak terjadi kesalahan dalam bekerja.

\section{KESIMPULAN DAN IMPLIKASI}

Berdasarkan penelitian yang telah penulis lakukan mengenai "Analisis pola rekrutmen dan seleksi karyawan di bank syariah (Studi di BRI Syariah Kantor Pusat Jakarta) maka penulis menyimpulkan sebagai berikut:

1. BRI Syariah merekrut karyawan dari sumber internal dan eksternal BRI Syariah merekrut karyawan dari sumber internal atau dari dalam perusahaan sendiri dan ketika ada lowongan di BRI Syariah mengumumkan kepada karyawannya melalui email, website, dalam merekrut 
karyawannya dari sumber eksternal BRI Syariah selalu mengikuti job fire dan bekerja sama dengan kampus, Ada 3 jalur perekrutan karyawan di bank BRI Syariah yaitu Jalur Officer Development Program (ODP), yaitu merekrut calon karyawan dari fresh graduate yang diposisikan sebagai tenaga marketing dan langsung ikatan dinas dengan BRI Syariah , Special Hire, yaitu merekrut calon karyawan yang berpengalaman untuk mengisi jabatan yang dibutuhkan perusahaan, Jalur outsourching yaitu merekrut karyawan yang diposisikan untuk tenaga kerja frontliner.

2. BRI Syariah Seleksi karyawan di BRI Syariah , Dalam praktek jenis seleksi karyawan antara rekrutmen internal dengan rekrutmen eksternalnya berbeda. Jika dilihat berdasarkan prosedur rekrutmen eksternal BRI Syariah , setelah lolos seleksi administrasi maka karyawan eksternal akan langsung tahap psikotes, wawancara dan tes kesehatan. Untuk seleksi dari internal ada wawancara dan asessment. Proses seleksi karyawan di BRI Syariah ini dilakukankan secara bertahap demi untuk mendapatkan kandidat yang berkompeten. Dengan metode ini, calon karyawan akan diuji kemampuannya dengan beberapa tes dan hasilnya akan dievaluasi oleh penyeleksi untuk diambil menjadi kandidat yang terbaik.

1. Memperluas bekerjasamanya dengan lembaga pendidikan, sekolah tinggi, maupun universitas dan lain-lain, untuk memperbanyak relasi dan mendapatkan kandidat-kandidat yang berkompeten. Sejauh ini kerjasama yang dilakukan oleh BRI Syariah salah satunya adalah UGM (Universitas Gajah Mada). Oleh karena itu perlu kerja sama dengan lembaga pendidikan yang banyak karena lembaga pendidikan merupakan yang mencetak menjadi tenaga kerja yang unggul. Sehingga ketika BRI Syariah membutuhkan karyawan akan lebih mudah untuk mendapatkanya.
2. Dengan melihat perbankan bank syariah saat ini dengan persaingan yang sangat ketat, BRI Syariah harus selalu memberikan kualitas yang terbaik dan memberikan pelayanan yang baik diberikan oleh masyarakat. Oleh karena BRI Syariah sebaiknya selalu berupaya untuk meningkatkan kualitas karyawankaryawan yang berkompeten, dan terus memberikan pelatihan-pelatihan mengenai perkembangan perbankan syariah saat ini.

\section{DAFTAR PUSTAKA}

Abdullah, Ma'ruf. 2013. Menejemen Berbasis Syariah, Yogyakarta: CV.Aswaja Pressindo.

Arikunto, Suharsimi. 2002 Prosedur Penelitian Suatu Pendekatan Praktek. Jakarta: PT. Rineka Cipta.

Bungin, Burhan. 2005. Metodologi Penelitian Kuantitatif. Jakarta: Prenada Media.

Catur p, Ahmad Ridho.2010. Analisis Kebijakan Menejemen SDM. Studi Modal Kebijakan, Rekrutmen, Seleksi Dan Penempatan, Serta Kompensasi Karyawan Pada PT.BNI Life Insurance/skripsi, jakarta. Program Studi Muamalat (Ekonomi Islam) Fakultas Syariah dan Hukum UIN Syarif Hidayatullah.

Denzin, Norman K., and Lincoln, Yvonna S. 1994. Handbook of qualitative research (terjemahan). Yogyakara: Pustaka Pelajar.

Fahmi, Abu dkk. 2014. HRD Syariah Teori dan Implementasi Menejemen Sumber Daya Manusia Berbasis Syariah, Jakarta: PT Gramedia Pustaka Utama.

Hanggraini, Dewi. 2012. Manajemen Sumber Daya Manusia, Jakarta: Lembaga Penerbit Fakultas Ekonomi Universitas Indonesia. 
Mardianto, Adi.2012. Recruitment Analysis. Jakarta: PT.Pinasthika Publisher.

Moleong, Lexy. 2002 Metode Penelitian Kualitatif, Bandung: PT. Remaja Rosda Karya.

Nuryanta, Nanang. 2008. Pengelolaan Sumber Daya Manusia (Tinjauan Aspek Rekrutmen Dan Seleksi)/jurnal. Vol 1. No1

Pahlevi, Rizal. 2013. Analisa Efektifitas Proses Rekrutmen Dan Seleksi Dalam Memenuhi Kebutuhan Sumber Daya Manusia(studi pada PT.Teknologi riset Global Investama)/ Jurnal. Jakarta. Program Studi Manajemen Bisnis Telekomunikasi Dan Informatika, Fakultas Ekonomi Dan Bisnis Universitas Telkom.

Rahmatika. 2014. Penerapan MSDM Berbasis Nilai-Nilai Islami Pada Bank BNI Syariah Semarang/Skripsi. Semarang. Program Studi Manajemen Fakultas Ekonomika Dan Program Studi Manajemen Fakultas Ekonomi Dan Bisnis, Universitas Diponegoro Semarang.

Rivai, Veithzal.2009.Islamic Human Capital Dari Teori Ke Pzraktik Manajemen Sumber Daya Insani, Jakarta:PT Grafindo Persada.

Salam, Abdus. 2014. Menejemen Insani dalam Bisnis, Yogyakarta: PT. Pustaka Pelajar.

Sedarmayanti. 2012. Metodologi Penelitian, Bandung: CV.Mandar Maju.

Septiana, Elza.2009. Penerapan Sistem Rekrutmen SDM Terhadap Kinerja Karyawan pada PT.BNI Syariah Cabang Padang/skripsi. diakses pada 19 februari 2009.

Sugiyono. 2010. Metode Penelitian Bisnis, Bandung: Alfabeta

Yulianti, Elly. 2009. Analisis Proses Rekrutmen Dan Seleksi Pada KinerjaPegawai/ Jurnal/DiaksesPada Sep-Des.
Zahra, Henni Fahmatus, 2009. Analisis Perencanaan Rekrutmen Tenaga Kerja Dalam Persepektif Islam (Studi Pada Koprasi Agroniaga Unit Jabang Malang)/Skripsi. Malang. Program Studi Manajemen, Fakultas Ekonomi, Universitas Maulana Malik Ibrahim Malang. 